\title{
How the Leopard Changed Its Spots
}





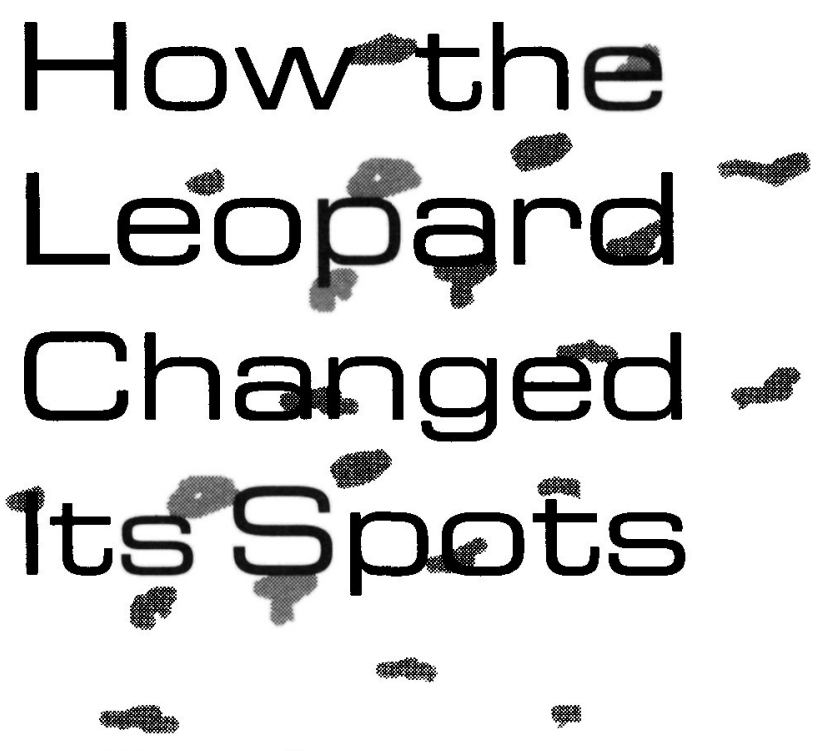

\section{THE EVOLUTION OF COMPLEXITY}

With a new preface by the author

Brian Goodwin

Princeton University Press

Princeton, New Jersey 
In the United States and Canada, published by Princeton University Press, 41 William Street, Princeton, New Jersey 08540

First published by CHARLES SCRIBNER'S SONS

1230 Avenue of the Americas

New York, New York 10020

SCRIBNERS and colophon are registered trademarks of Macmillan, Inc.

Copyright (C) 1994 by Brian Goodwin

New preface Copyright (C 2001 by Brian Goodwin

All rights reserved, including the right to reproduce this book or portions thereof in any form whatsoever.

First Princeton edition, with new preface, 2001

Library of Congress Cataloging-in-Publicaton Data

Goodwin, Brian C.

How the leopard changed its spots : the evolution of complexity $/$

Brian Goodwin.

p. cm. - (Princeton science library)

Originally published: New York : C. Scribner's Sons, 1994. With a new preface by the author.

Includes bibliographical references and index.

ISBN 0-691-08809-8 (pbk. : alk. paper)

1. Evolution (Biology) 2. Morphology. 3. Self-organizing

systems. I. Title. II. Series.

QH366.2 .G655 2001

$576.8-\mathrm{dc} 21$

00-051652

This book has been composed in Sabon

Printed on acid-free paper. $\infty$

www.pup.princeton.edu

Printed in the United States of America

$\begin{array}{llllllllll}10 & 9 & 8 & 7 & 6 & 5 & 4 & 3 & 2 & 1\end{array}$ 